\title{
Use of Biomaterials for Periodontal Regeneration: A Review
}

\author{
Bylbyl F. Reçica ${ }^{1 *}$, Mirjana Popovska ${ }^{2}$, Amella Cana $^{3}$, Lindita Zendeli Bedxeti ${ }^{2}$, Urim Tefiku ${ }^{4}$, Spiro Spasovski $^{5}$, \\ Ana Spasovska-Gjorgovska ${ }^{6}$, Teuta Kutllovci ${ }^{7}$, Jehona F. Ahmedi ${ }^{8}$
}

${ }^{1}$ Department of Dental Emergency, University Dental Clinical Centre, Pristina, Kosovo; ${ }^{2}$ Department of Periodontology and Oral Pathology, University Dental Clinical Centre, Faculty of Dentistry, "Ss. Cyril and Methodius University", Skopje, Republic of Macedonia; ${ }^{3}$ Department of Orthodontics, University Dental Clinical Centre, Skopje, Republic of Macedonia; "Denta Med" - Desmoret e Golakut n.n., Pristina, Kosovo; "Dr. Spasovski”, Skopje, Republic of Macedonia; ${ }^{6}$ PZU "llinden 96, Skopje, Republic of Macedonia; ${ }^{7}$ Department of Pedodontics and Preventive Dentistry, University Clinical Centre of Kosovo, Pristina, Kosovo; ${ }^{8}$ Department of Oral Surgery, University Dental Clinical Center Pristina, Pristina, Kosovo

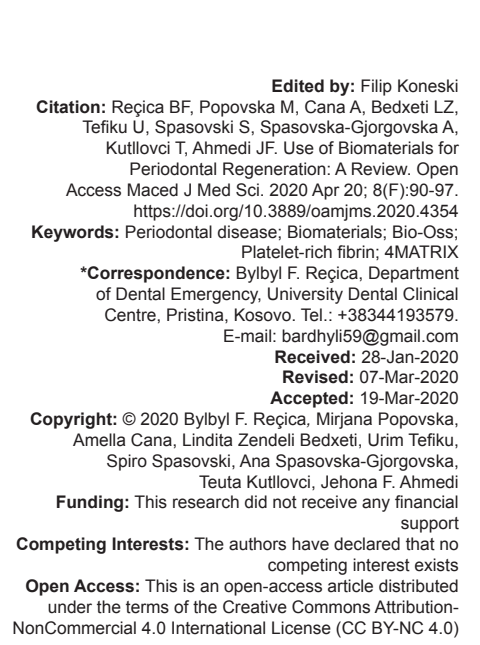

\section{Introduction}

Periodontal disease is not new. Archeological investigations have revealed evidence of alveolar bone loss affecting human remains dating from around 700,000 years ago [1].

The main chronic infective disease of the gums that affects around $10-30 \%$ of the adult population is periodontitis.

Bacteria, present in the dental plaque, are capable of inducing an inflammatory response of the periodontal tissues. In susceptible individuals, this chronic inflammation will induce a breakdown of the periodontal ligament (PDL) and the surrounding alveolar bone resulting in the formation of periodontal pockets around the roots, thus causing periodontitis [2].

Periodontitis, the main cause of tooth loss in adults, is characterized by the bacterially induced inflammation, which frequently results in the formation of intrabony defects. It affects the supporting structures of the teeth, including the jawbone, PDL, and cementum. Apart of functional and esthetic problems in the oral cavity, periodontitis is being associated with systemic diseases, such as diabetes, preterm birth, cardiovascular disease, stroke, and pulmonary disease as well [3]. The ultimate involves the formation of new cementum on the tooth root, along with new periodontal attachment between newly formed bone and cementum [4].

Periodontitis is a disease characterized by pathological processes that involve all structures around the tooth (periodontium, cement, alveolar bone, and gingiva). During the development of the disease, complex and irreversible mechanisms induce bone destruction and resorption, which definitely leads to tooth loss [5]. It is commonly known that periodontal disease results in different types of alveolar bone defects. One of them is periodontal pockets which 
represent the most important clinical sign of periodontal disease, thus are considered basic pathognomonic features of this very frequent disease present in the population [6], [7].

\section{History}

Descriptions of conditions that we would now refer to as periodontitis can be found in a number of ancient textbooks, papyruses, and manuscripts, such as Al-Tasrif, the medical encyclopedia written by Albucasis (936-1013) in Moorish Spain. In addition to the clinical features of periodontitis, some of these early authors also described treatment strategies for this condition.

If we spend a moment to imagine the likely oral health status of many of the people living in the Middle Ages, in the time of Albucasis, for example, we would probably conjure up images of abundant calculus deposits, inflamed gingival tissues, gingival bleeding, and halitosis. In the United States of America, Riggs (1810 1885) regarded calculus as the cause of periodontal disease, thus treated the condition by meticulous removal of calculus from pockets, "curettage" of the soft tissues and oral hygiene instruction. Furthermore, the etiological role of plaque in the development of gingival inflammation was confirmed in experimental studies on gingivitis conducted in the 1960s: Upon cessation of oral hygiene practices over periods of 3-4 weeks, plaque accumulation resulted in gingivitis, which was reversed following plaque removal and resumption of normal oral hygiene [8]

Studies on the natural history of periodontitis performed in Sri Lankan tea plantation workers between 1970 and 1985 provided basic information on oral conditions unaffected by any dental monitoring, prophylaxis or therapy and in the absence of any professionally recommended or supervised oral hygiene practices over a period of 15 years [9]. A subsequent examination of this distinct Cohort in 1990 confirmed the ongoing progression of periodontitis and the influence of tobacco consumption or betel nut chewing on attachment loss and periodontitis-related tooth loss over 20 years [10]. While clinical data from these studies generally suggested an overall increase in both prevalence and severity of the disease with advancing age, different disease progression rates within the subjects were recognized. Consequently, three subgroups of subjects were identified with various periodontal disease progression rates: (1) Rapid progression, in approximately $8 \%$ of the subjects, (2) moderate progression, in approximately $81 \%$ of the subjects, and (3) minimal progression, in approximately $11 \%$ of the subjects. Over a period of 15 years, the annual rates of clinical attachment loss in these three subgroups were up to $1.0 \mathrm{~mm}$ in the first group, $0.5 \mathrm{~mm}$ in the second group, and $0.1 \mathrm{~mm}$ in the third group [11].
Already some 4000 years ago, the ancient Egyptians and Chinese described periodontal diseases as inflammatory conditions, and Hippocrates (460335B.C.) discussed the etiology and pathogenesis of different forms, including the situation when "the gums were bleeding or rotten" [12].

The early Hebrews Jews, the Romans, and later the Arabs of the middle ages contributed in various ways to the description and treatment of these diseases. However, it is probably fair to consider the 1746 publication of Pierre Fauchard [13] and Le Chirurgien Dentiste, as providing the first discussion of periodontal pathology and therapy with some modicum of intellectuality and usefulness. Fauchard recommended thorough scaling of the teeth with special instruments to remove calculus. He also prescribed mouthwashes, dentifrices, and the splinting of loose teeth.

The early English contribution to the understanding and management of periodontal diseases was made by John Hunter, a physiologist and surgeon of broad intellectual and scientific interests, widely known for his 1771 work on the natural history of the human teeth [14]. In another major work from 1802, a practical treatise on the diseases of the teeth, Hunter proposed a classification of the periodontal diseases that identified inflammatory processes in the gingiva as important factors in the resorption of the alveolar bone [15].

\section{Etiology}

The term "endotoxin" was first introduced to denote toxic substances within bacterial cells that were released upon the death of the bacteria. Today, the term is used synonymously with the term "lipopolysaccharide," which is a component of the outer cell wall of Gram-negative bacteria. It was hypothesized that this endotoxin would limit the effectiveness of periodontal therapy because even if plaque and calculus were removed from the root surface, the endotoxin still presents in the cementum would continue to irritate the tissues and thus compromise healing following treatment. This presumption led to the preeminence of the treatment concept known as "root planning," often combined as a treatment strategy with scaling, and abbreviated as "scaling and root planning."

\section{Periodontal Regeneration and Biomaterials}

Management of bone periodontal defects, destruction, and loss of the alveolar bone in the upper 
or lower jaw is considered a challenge for modern periodontal regeneration and implant dentistry [16].

There are numerous of biomaterials that are being used in the regenerative therapy of periodontal disease such as Straumann ${ }^{\circledR}$ Emdogain ${ }^{\circledR}$, Geistlich BioOss ${ }^{\circledR}$ made from the mineral part of bovine bone, MIS 4MATRIX - Bone Graft, and Platelet-rich fibrin (PRF).

The first step in the periodontal treatment procedures is the removal of supra and subgingival concernments deposits but in parallel with that an individual approach in educating and motivating patients to maintain oral hygiene, and then processing the hard and soft wall of the periodontal pocket, removal of granulation, ulceration and proliferation from the soft wall, polishing the root surface, and, where necessary, planning, and performing periodontal surgery. After the applied therapeutic procedures, it is possible to eliminate or reduce the depth of the periodontal pockets and to create a new junction epithelium [17]. The ultimate goal of any periodontal therapy is not only to prevent the progression of periodontal disease but also to regenerate the architecture and function of the periodontal complex, which involves the formation of a new cement of the root of the tooth, as well as a new epithelial attachment [4], and motivating patients to maintain proper oral hygiene.

Number of therapeutic modalities, nonsurgical, and surgical procedures, and aim to prevent progressive attachment loss, reduce probing pocket depths (PPD) and control both systemic and local risk factors associated with periodontal disease. In this literature review, we are going to highlight some of biomaterials and procedures which involve directly in periodontal.

One of the most important interventions recommended in this domain is guided tissue regeneration (GTR/guided bone regeneration). It is a surgical procedure that is aimed at restoring periodontal tissues. In general, the goal of periodontal therapy is the elimination of deep periodontal pockets. The treatment of periodontitis is cause-related, so it should be known the cause of periodontitis to treat and fight against that. The first step is to mechanically clean periodontal pockets from bacteria (debridement). The crucial role for the success of the therapy is the patient's home plaque control since pockets can be recolonized by bacteria in a few weeks. In the presence of deep pockets, surgery may also be indicated to get access to the deepest portions of the pockets to properly clean them and to reduce the depth of the pockets. The goal of this treatment approach is healing by repair without the formation of new periodontal attachment [18]. This can be done by different types of bone grafts, membranes, growth factors, etc. Using the grafts, we try to help the regeneration of lost periodontal tissue. There are many original papers which are talking about regenerative therapy in the treatment of periodontal intrabony defects. The main parameters that we check after regenerative therapy are plaque index, papillary bleeding index, and PPD. The ideal treatment would be to recover the periodontal tissues that have been lost (periodontal tissue regeneration). Several surgical techniques have been developed in the attempt to regenerate periodontal tissues, including GTR, bone grafting (BG), and the use of the enamel matrix derivative (EMD). All these treatments have been shown to have the potential to regenerate at least some periodontal attachment in humans [19]. Its seen that the effects of Enamel Matrix Derivative and Natural Bone Mineral with Platelet-Rich Plasma on the Healing of Intrabony Defects Treated was treated very good by Döri et al. where the use of PRP does not appear to improve the results obtained with EMD+NBM (Table 1) [20]. To compare mandibular bone regeneration by applying autologous bone, plateletrich plasma and two biomaterials (synthetic calcium hydroxyapatite, and demineralized bone matrix), and thus establish the potential benefits of these biomaterials in the regeneration of post extraction alveolar bone the faster bone formation occurred in the groups where are used autologous bone and demineralized bone matrix, respectively (Table 1) [21].

Periodontal regeneration mediated by EMD is based on a different concept. The enamel matrix is composed of a number of proteins, $90 \%$ of which is amelogenin. The only commercially available product using EMD is called Emdogain and is produced by Biora (Malmö, Sweeden). One year after treatment of periodontal resorption by EMD showed statistically significant improvements in probing attachment levels $(1.3 \mathrm{~mm})$ and PPD reduction $(1 \mathrm{~mm})$ in comparison with flap surgery. However, the actual clinical advantages might be questioned since there is not yet evidence that more teeth can be saved using EMD. No evidence of major differences between EMD and GTR could be found with the expectation slightly more PPD reduction $(0.6 \mathrm{~mm})$ due to increased gingival recession (REC) $0.5 \mathrm{~mm}$ in GTR treated sites. On the other hand, EMD seems simpler to use, may not need antibiotic coverage and does not need a second surgical intervention (if compared with non-resorptive barriers). In addition, no post-operative infections or adverse events were observed with EMD versus two cases of infection (not statistically significant) in the GTR group.

Some clinical study recommends the use of Bio-Oss deproteinized bovine bone mineral alone or in combination with Emdogain for surgical regenerative procedure in human periodontal intrabony defects. In the study by Koop et al. [22], the use of Bio-Oss combined with EMD-Emdogain as a biologic factor in consistence with the regenerative surgical procedure is recommended for the periodontal healing. The conclusion of this study was that in the treatment of intrabony defects, the use of EMD is superior to control treatments but as effective as resorbable membranes. The additional use of EMD with a coronally advanced flap for REC coverage will give superior results compared with control but is as effective as a connective tissue graft. The use of EMD in furcations will give more 
Table 1: Studies of different biomaterials used for periodontal regeneration

\begin{tabular}{|c|c|c|c|c|c|}
\hline Authors & Application of & Year publication & Follow-up & Main results & Reference \\
\hline Koop et al. & Enamel Matrix Derivative & 2012 & 12 months & Effective in reduction of horizontal furcation & [22] \\
\hline Najeeb et al. & PRF with open flap debridement & 2017 & 12 months & Very god outcomes in regenerative therapy & [23] \\
\hline Hou et al. & PRP in treatment of intrabony defects & 2016 & 6 months & $\begin{array}{l}\text { PRP together with conventional grafting procedures may } \\
\text { be a beneficial treatment approach }\end{array}$ & [24] \\
\hline Stavropoulos and Karring & GTR with bioabsorbable membranes+DBB (Bio-Oss) & 2005 & 5 years & $\begin{array}{l}\text { GTR with bioabsorbable membranes in combination with } \\
\text { Bio-Oss is basically stable on a long-term basis }\end{array}$ & [25] \\
\hline Agarwal et al. & PRF+DFDBA & 2016 & 12 months & PRF+DFDBA more effective than DFDB with saline & [26] \\
\hline Pradeep et al. & Platelet Rich Fibrin with $1 \%$ Metformin & 2015 & 9 months & $\begin{array}{l}\mathrm{PRF}+1 \% \mathrm{MF} \text { group showed better results in clinical } \\
\text { parameters and radiograph defect depth reduction } \\
\text { compare to MF, PRF, or OFD alone }\end{array}$ & [27] \\
\hline Shah et al. & PRF+DFDBA & 2012 & 12 months & $\begin{array}{l}\text { PRF shows comparable results to DFDBA in terms of } \\
\text { clinical parameters }\end{array}$ & [28] \\
\hline Lekovic et al. & PRF and BPBM & 2012 & 6 months & $\begin{array}{l}\text { Both PRF and PRF-BPBM groups showed significant } \\
\text { pocket depth reduction at } 6 \text { months compared with } \\
\text { baseline }\end{array}$ & [29] \\
\hline Panda et al. & Autologous platelet concentrates (APCs) & 2016 & 9 months & $\begin{array}{l}\text { APCs in surgical treatment of intrabony defects have been } \\
\text { increasing in recent years }\end{array}$ & [30] \\
\hline Esposito et al. & Emdogain & 2009 & & Very good regenerative effect on bone healing & [2] \\
\hline Galgut & Biodegradable oxidized cellulose and hydroxyapatite & 1990 & 8 weeks & $\begin{array}{l}\text { Guided tissue regeneration techniques have been shown } \\
\text { to enhance new attachment formation with minimal post- } \\
\text { operative recession }\end{array}$ & [31] \\
\hline Kökdere et al. & $\begin{array}{l}\text { PRF and PRF-mixed particulate autogenous bone } \\
\text { graft }\end{array}$ & 2015 & 2 months & $\begin{array}{l}\text { PRF increase new bone formation and has a positive } \\
\text { effect on early bone healing }\end{array}$ & [32] \\
\hline Albanese et al. & PRP from the wound healing to bone regeneration & 2013 & 12 months & Positively influence bone regeneration & [33] \\
\hline Célio-Mariano et al. & $\begin{array}{l}\text { Autologous platelet rich plasma after impacted third } \\
\text { molar mandible surgery }\end{array}$ & 2012 & 6 months & $\begin{array}{l}\text { Autologous PRP was found to accelerate alveolar bone } \\
\text { regeneration, and men presented better repair after tooth } \\
\text { extraction }\end{array}$ & [34] \\
\hline Dohan et al. & Platelet-rich fibrin (PRF & 2006 & 6 months & $\begin{array}{l}\text { The biologic activity of the fibrin molecule is enough in } \\
\text { itself to account for the significant cicatricle capacity of } \\
\text { the PRF }\end{array}$ & [35] \\
\hline Arenaz-Búa et al. & $\begin{array}{l}\text { Platelet-rich plasma, hydroxyapatite, demineralized } \\
\text { bone matrix, and autologous bone }\end{array}$ & 2009 & 10 days & $\begin{array}{l}\text { The faster bone formation occurred in the groups where } \\
\text { we used autologous bone and demineralized bone matrix, } \\
\text { respectively }\end{array}$ & [21] \\
\hline Kobayashi et al. & $\begin{array}{l}\text { Comparative release of growth factors from PRP, } \\
\text { PRF, and advanced-PRF }\end{array}$ & 2016 & 10 days & $\begin{array}{l}\mathrm{PRP} \text { can be recommended for fast delivery of growth } \\
\text { factors whereas A-PRF is better-suited for long-term } \\
\text { release. }\end{array}$ & [36] \\
\hline Needleman et al. & $\begin{array}{l}\text { Guided tissue regeneration for periodontal infra-bony } \\
\text { defects }\end{array}$ & 2012 & 12 months & $\begin{array}{l}\text { GTR has a greater effect on probing measures of } \\
\text { periodontal treatment than open flap debridement }\end{array}$ & [37] \\
\hline Sebben et al. & $\begin{array}{l}\text { Platelet-rich plasma alone and in combination on with } \\
\text { alpha-tricalcium phosphate cement }\end{array}$ & 2012 & 8 weeks & $\begin{array}{l}\text { The data from this study suggest that treatment with } \\
\alpha-T C P \text { cement combined with PRP does not show any } \\
\text { significant difference in comparison with PRP alone }\end{array}$ & [38] \\
\hline Ozdemir and Okte & $\begin{array}{l}\text { Beta-tricalcium phosphate alone and in combination } \\
\text { with platelet-rich plasma }\end{array}$ & 2011 & 6 months & $\begin{array}{l}\text { After } 6 \text { months, both treatment modalities showed } \\
\text { statistically significant clinical and radiographically } \\
\text { improvements }\end{array}$ & [39] \\
\hline Döri et al. & $\begin{array}{l}\text { Platele-trich plasma enamel matrix derivative and } \\
\text { natural bone mineral }\end{array}$ & 2013 & 5 years & $\begin{array}{l}\text { (1) The clinical outcomes obtained with both treatments } \\
\text { can be maintained up to a period of } 5 \text { years and ( } 2 \text { ) } \\
\text { the use of PRP does not appear to improve the results } \\
\text { obtained with EMD+NBM }\end{array}$ & [20] \\
\hline
\end{tabular}

reduction in horizontal furcation defect depth compared with resorbable membranes.

The results of the study of Gojkov-Vukelic et al. [40] using Maxresorb (Botiss dental) as regenerative grafts in periodontal pockets showed a significant reduction in probing depth for both groups of patients (treated by open flap surgery and treated by open flap surgery in addition with Maxresorb), 1 and 6 months after the performed surgical therapy. By comparing the results between the groups, they did not get significantly better results for Group 2, where Maxresorb was used as bone replacement. This research is the opposite with findings of the study by Gokhale [41], whose results showed significant improvement for clinical parameters at sites treated with Bio-Oss compared to control sites.

In the research by Shivjot Chhina comparing of treatment results using standard flap surgery and flap surgery with the addition of free gingival graft revealed better treatment outcomes in the group with free gingival graft [42]. The conclusion was that the treatment of supracrestal defects with a combination of open flap debridement (OFD) and SECTG led to significantly better clinical results compared to OFD alone.
Results from meta-analysis indicated that the treatment of periodontal bone defects with intraoral BGs in periodontal regeneration is not always predictable [43]. The literature review of GTR in a lot of case studies has shown that this procedure is more effective than OFD, with an additional gain in clinical attachment level of $1.2 \mathrm{~mm}$ [37].

Platelet-rich plasma(PRP)is autologous plasma which has been enriched with platelets and leukocytes in addition to jellifying agents, growth factors, cytokines, bovine thrombin, and anticoagulants [44], [45]. One of the drawbacks of PRP is the fact that it has liquid nature and therefore required its combination with other biomaterials, including bone grafts derived from human cadavers (allografts) or animal products (xenografts). Data points out to the quick "burst" release of growth factors from PRP [46].

In many reviews, we noticed that PRP has been used as a regenerative substituent to promote wound healing and tissue regeneration [47]. Comparing with PRF, PRP has some limitations because the growth factors are released for a very short period of time, also the bovine clotting factors may react with human clotting factors to give rise to bleeding. There 
is a reason that PRF as a second-generation platelet derivative, called PRF has been used in regenerative medicine and dentistry [35], [48], [49]. One of the main differences between PRF and previously utilized PRP is the incorporation of leukocytes in PRF. Several studies have shown their key importance during anti-infectious pathogen resistance, as well as their implications in immune regulation [50], [51], [52]. The platelet-rich fibrin when combined with open-flap debridement produces better outcomes compared to the open flap debridement alone. The regenerative potential of platelet-rich fibrin results in better augmentation and regeneration of periodontal bone defects (Table 1) [23]. The adjunctive use of PRP together with conventional grafting procedures may be a beneficial treatment approach. However, when combined with the use of a regenerative technique, such as GTR, the beneficial effect of PRP on the treatment of intrabony defects is negligible (Table 1) [24]

By used of GTR with bio absorbable membranes in combination with Bio-oss are basically stable on a long term basis and the clinical and radiographical data from baseline and from the 1- and 5-year control wich are presented on this article treatment resulted in statistically significant clinical improvements (i.e., PPD reduction, PAL gain) 1 year after surgery, which were preserved during the following 4- year observation period. PPD had increased to a minor extend $(0.4 \mathrm{~mm})$ from the 1 - to the 5-year control visit, but the average amount of residual PPD was not significantly different between the two observation periods (Table 1) [25].

In usage of demineralized freeze-dried bone allograft (DFDBA) alone with saline and PRF with DFDBA the 12-month results indicated that both treatment modalities resulted in significant changes in all clinical and radiographic parameters. However, the PRP/DFDBA group exhibited statistically significantly greater changes compared with the DFDBA/saline group in PD, CAL, REC,bone fill and defect resolution table (Table1) [26].

Treatment of furcation defects with RSV $1.2 \mathrm{mg}$ in situ gel combined with autologous PRF and porus-HA bone graft, results in significant improvements of clinical and radiographic parameters when compared with OFD alone. Combining RSV with PRF and HA, implies their synergestic effects explaining their role as a regenerative material in the treatment of furcation defects (Table1) [27].

PRF shows comparable results to DFDBA in terms of clinical parameters (Table 1) [28].

The results of this study indicate that PRF can improve clinical parameters associated with human intrabony periodontal defects, and BPBM has the ability to augment the effects of PRF in reducing pocket depth, improving clinical attachment levels and promoting defect fill (Table 1) [29].

Based on the results obtained from the systematic review by Panda et al.can be concluded that the evidence on the beneficial additive effect of APCs in surgical treatment of intrabony defects has been increasing in recent years (Table 1) [30].

By using Biodegradable oxidized cellulose and hydroxyapatite Guided tissue regeneration techniques have been shown to enhance new attachment formation with minimal post- operative recession (Table 1) [31].

PRF alone or PRF-mixed particulate autogenous bone increase new bone formation and has a positive (Table 1) [32]. The use of PRP in the alveolar socket after tooth extractions is certainly able to improve soft tissue healing and positively influence bone regeneration but this latter effect seems to decrease a few days after extraction (Table 1) [33].

Analysis of radiographic bone density by periods 1,2 , and 3 months after extraction of impacted mandibular third molars bilaterally where in one side was used PRP and in other side just blood clot there were favorable significant differences for the PRP group. At 7 days and at 6 months, there were no statistical differences; however, higher means of radiographic bone density were observed in the PRP group (Table 1) [34].

To compare mandibular bone regeneration by applying autologous bone, platelet-rich plasma and two biomaterials (synthetic calcium hydroxyapatite, and demineralized bone matrix), and thus establish the potential benefits of these biomaterials in the regeneration of post extraction alveolar bone the faster bone formation occurred in the groups where are used autologous bone and demineralized bone matrix, respectively (Table 1) [21].

PRP, PRF, and A-PRF were able to release growth factors over time from their respective platelet formulations. Interestingly, PRP demonstrated the ability to release significantly higher levels of growth factors at very early time points whereas PRF and A-PRF had a more gradual release of growth factors up to a 10-day period (Table 1) [36].

By compare the effect of alpha-tricalcium phosphate ( $\alpha$-TCP) cement combined with platelet-rich plasma (PRP) on osteogenesis, and to compare the results with use of PRP alone was seen that treatment with $\alpha-T C P$ cement combined with PRP does not show any significant difference in comparison with PRP alone (Table 1) [38].

Beta-tricalcium phosphate alone and in combination with platelet-rich plasma as modalities for treatman of intrabony defects showed significant clinical radiographically improvements (Table 1) [39].

Unlike PRP, PRF contains a fibrin matrix instead of jellifying agents and bovine clotting factors [53]. It is important to note that PRF contains a number of cells, including platelets, leukocytes, macrophages, granulocytes, and neutrophils. Furthermore, PRF exhibits a slow and sustained release of growth factors, such as transforming growth factor-b1, platelet-derived growth factor, and vascular endothelial growth factor which all have been proven to promote the wound healing and tissue regeneration [54]. 
The PRF when combined with open-flap debridement and combined by GTR produces better outcomes and better regenerative power compared to the OFD alone. The regenerative potential of PRF results in better augmentation and regeneration of periodontal bone defects. In addition, PRF may augment the regenerative potential of bone grafts. However, more long term and well-designed clinical trials are needed to ascertain the clinical efficacy of PRF and PRF containing bone grafts.

MIS 4MATRIX bone grafts is a new synthetic bone replacement product that helps in bone dental replacement procedures. The 4MATRIX composition is pure $66.6 \%$ biphasic calcium sulfate (BCS) and $33.3 \%$ hydroxyapatite (HA) and is characterized by predetermined setting time and resorption rate. 4MATRIX is the preferred augmenting-replacement product for a wide variety of dental bone replacement procedures.

Considering the bone regeneration, resorption rate and stabilization 4MATRIX have its advantages. During the administration procedure, the 4MATRIX BCS component remains intact in the presence of blood and saliva and stimulates bone growth when placed in contact with the bone or periosteum. 4MATRIX consists of two different components. BCS has a complete resorption rate in close connection with bone formation rate (4-10 weeks), while HA acts as a long-term spatial maintainer. A component such as HA contributes to the maintenance of longer-term space and provides higher mechanical strength and stabilization of new regenerated bone grafts.

\section{Conclusion}

Biomaterials being used in periodontal surgical treatment have the different regenerative ability. The combined use of biomaterials might result in a better clinical outcome.

\section{References}

1. Dentino A, Lee S, Mailhot J, Hefti AF. Principles of periodontology. Periodontol 2000. 2013;61(1):16-53. https://doi. org/10.1111/j.1600-0757.2011.00397.x

\section{PMid:23240942}

2. Esposito M, Grusovin MG, Papanikolaou N, Coulthard $P$ Worthington HV. Enamel matrix derivative (Emdogain $(R))$ for periodontal tissue regeneration in intrabony defects. Cochrane Database Syst Rev. 2009;4:CD003875. https://doi. org/10.1002/14651858.cd003875

PMid:19821315

3. Pihlstrom BL, Michalowcz BS, Johmson NW. Periodontal diseases. Lancet. 2005;366(9499):1809-20.

PMid: 16298220

4. Wang HL, Greenwell H, Fiorellini J, Giannobile W, Offenbacher S Salkin L, et al. Periodontal regeneration. J Periodontol. 2005;76(9):1601-22.

PMid: 16171453

5. Savage A, Eaton KA, Moles DR, Needleman I. A systematic review of definitions of periodontitis and methods that have been used to identify this disease. J Clin Periodontol. 2009;36(6):45867. https://doi.org/10.1111/j.1600-051x.2009.01408.x

PMid:19508246

6. Greenstein G, Lamster I. Changing periodontal paradigms: Therapeutic implications. Int J Periodontics Restorative Dent. 2000;20(4):337-57.

PMid:11203574

7. Glickman I, Smulow JB. Periodontal Diseas: Clinical Radiographic and Histopathologic Features. Philadelphia, PA: Saunders; 1974.

8. Loe H, Silness J. Periodontal disease in pregnancy I. Prevalence and severity. Acta Odontol Scand. 1963;21:533-51. https://doi. org/10.3109/00016356309011240

PMid:14121956

9. Löe $\mathrm{H}$. Progress in improving dental health a discussion J Public Health Dent. 1978;38(4):329-32. https://doi. org/10.1111/j.1752-7325.1978.tb03758.x

10. Neely JG. Clinical experience with a surgical approach to hydrops. Ann N Y Acad Sci. 2001;942:322-7.

PMid:11710474

11. Löe H. Periodontology in the past 20 years. Tandlaegebladet. 1986;90(18):788-94. PMid:3468647

12. Mitsis FJ. Hippocrates in the golden age. His life, his work 79-83. J Periodontol. 1965;36:177-87.

13. Faurhard P. Le Chirurgien-Dentiste. $2^{\text {nd }}$ ed. Paris: Mariet-Le, 1746. p. 1-494.

14. Hunter J. The Natural History of the Human Teeth, Explaining Their Structure Use, Formation, Growth and Disease. London: Johnson; 2007. p. 1-128.

15. Hunter J. A practical treatise on the diseases of the teeth. In: Longbottom B, editors. A Treatise on Dentistry. Baltimore: Prentiss and Cole; 1802. p. 1-66.

16. Krayer JW, Rees TI. Histologic observation on the topography of a human periodontal pocket viewed intransverse stepserial section. J Periodontol. 1993;58(3):122-34. https://doi. org/10.1902/jop.1993.64.7.585

17. Haffajee $A D$, Cugini MA, Dibart S, Smith C, Kent RL Jr. Socransky SS. The effect of SRP on the clinical and microbiological parameters of periodontal diseases. J Clin Periodontol. 1997;24(5):324-34. https://doi.org/10.1111/j.1600051x.1997.tb00765.x PMid:9178112

18. Bowers GM, Chadroff B, Carnevale R, Mellonig J, Corio R, Emerson $\mathrm{J}$, et al. Histologic evaluation of new attachment apparatus formation in humans. Part I. J Periodontol. 1989;60(12):664-74. https://doi.org/10.1902/jop.1989.60.12.664 PMid:2614631

19. Bowers GM, Chadroff B, Carnevale R, Mellonig J, Corio R, Emerson $\mathrm{J}$, et al. Histologic evaluation of new attachment apparatus formation in humans. Part II. J Periodontol. 1989;60(12):675-82. https://doi.org/10.1902/jop.1989.60.12.675 PMid:2614632

20. Döri F, Arweiler N, Húszár T, Gera I, Miron RJ, Sculean A. Fiveyear results evaluating the effects of platelet-rich plasma on the healing of intrabony defects treated with enamel matrix derivative 
and natural bone mineral. J Periodontol. 2013;84(11):1546-55. https://doi.org/10.1902/jop.2013.120501

PMid:23327604

21. Arenaz-Búa J, Luaces-Rey $R$, Sironvalle-Soliva $S$, OteroRico A, Charro-Huerga E, Patiño-Seijas B, et al. A comparative study of platelet-rich plasma, hydroxyapatite, demineralized bone matrix and autologous bone to promote bone regeneration after mandibular impacted third molar extraction. Med Oral Patol Oral Cir Bucal. 2010;15(3):e483-9. https://doi.org/10.4317/ medoral.15.e483

PMid:20038911

22. Koop R, Merheb J, Quirynen M. Periodontal regeneration with enamel matrix derivative in reconstructive periodontal therapy: A systematic review. J Periodontol. 2012;83(6):707-20. https:// doi.org/10.1902/jop.2011.110266

PMid:22050544

23. Najeeb S, Khurshid Z, Agwan MA, Ansari SA, Zafar MS, Matinlinna JP. Regenerative potential of platelet rich fibrin (PRF) for curing intrabony periodontal defects: A systematic review of clinical studies. Tissue Eng Regen Med. 2017;14(6):735-42. https://doi.org/10.1007/s13770-017-0079-5

PMid:30603523

24. Hou X, Yuan J, Aisaiti A, Liu Y, Zhao J. The effect of plateletrich plasma on clinical outcomes of the surgical treatment of periodontal intrabony defects: A systematic review and meta-analysis. BMC Oral Health. 2016;16(1):71. https://doi. org/10.1186/s12903-016-0261-5

PMid:27531202

25. Stavropoulos A, Karring T. Five-year results of guided tissue regeneration in combination with deproteinized bovine bone (Bio-Oss) in the treatment of intrabony periodontal defects: A case series report. Clin Oral Investig. 2005;9(4):271-7. https:// doi.org/10.1007/s00784-005-0002-7 PMid:16010581

26. Agarwal A, Gupta ND, Jain A. Platelet rich fibrin combined with decalcified freeze-dried bone allograft for the treatment of human intrabony periodontal defects: A randomized split mouth clinical trail. Acta Odontol Scand. 2016;74(1):36-43. https://doi. org/10.3109/00016357.2015.1035672

PMid:25972081

27. Pradeep AR, Karvekar S, Nagpal K, Patnaik K, Raju A, Singh P. Rosuvastatin $1.2 \mathrm{mg}$ in situ gel combined with 1: 1 mixture of autologous platelet-rich fibrin and porous hydroxyapatite bone graft in surgical treatment of mandibular class II furcation defects: A randomized clinical control trial. J Periodontol. 2016;87(1):5-13. https://doi.org/10.1902/jop.2015.150131 PMid:26439386

28. Shah M, Patel J, Dave D, Shah S. Comparative evaluation of platelet-rich fibrin with demineralized freeze-dried bone allograft in periodontal infrabony defects: A randomized controlled clinical study. J Indian Soc Periodontol. 2015;19(1):56-60. https://doi. org/10.4103/0972-124x.145803

PMid:25810594

29. Lekovic V, Milinkovic I, Aleksic Z, Jankovic S, Stankovic P, Kenney EB, Camargo PM. Platelet-rich fibrin and bovine porous bone mineral vs. Platelet-rich fibrin in the treatment of intrabony periodontal defects. J Periodontal Res. 2012;47(4):409-17. https://doi.org/10.1111/j.1600-0765.2011.01446.x PMid:22126591

30. Panda S, Doraiswamy J, Malaiappan S, Varghese SS, Del Fabbro M. Additive effect of autologous platelet concentrates in treatment of intrabony defects: A systematic review and metaanalysis. J Investig Clin Dent. 2016;7(1):13-26. https://doi. org/10.1111/jicd.12117

PMid:25048153
31. Galgut PN. Oxidized cellulose mesh. II. Using hydroxyapatite bone grafting material in the treatment of infrabony defects. Biomaterials. 1990;11(8):565-7. https://doi. org/10.1016/0142-9612(90)90079-6

PMid:2279058

32. Kökdere NN, Baykul T, Findik Y. The use of platelet-rich fibrin (PRF) and PRF-mixed particulated autogenous bone graft in the treatment of bone defects: An experimental and histomorphometrical study. Dent Res J (Isfahan). 2015;12(5):418-24. https://doi.org/10.4103/1735-3327.166188 PMid:26604954

33. Albanese A, Licata ME, Polizzi B, Campisi G. Platelet-rich plasma (PRP) in dental and oral surgery: From the wound healing to bone regeneration. Immun Ageing. 2013;10(1):23. https://doi.org/10.1186/1742-4933-10-23

PMid:23763951

34. Célio-Mariano R, de Melo WM, Carneiro-Avelino C. Comparative radiographic evaluation of alveolar bone healing associated with autologous platelet-rich plasma after impacted mandibular third molar surgery. J Oral Maxillofac Surg. 2012;70(1):19-24. https:// doi.org/10.1016/j.joms.2011.03.028

PMid:21778014

35. Dohan DM, Choukroun J, Diss A, Dohan SL, Dohan AJ, Mouhyi J et al. Platelet-rich fibrin (PRF): A second-generation platelet concentrate. Part I: Technological concepts and evolution. Oral Surg Oral Med Oral Pathol Oral Radiol Endod. 2006;101(3):e3744. https://doi.org/10.1016/j.tripleo.2005.07.008 PMid: 16504849

36. Kobayashi E, Flückiger L, Fujioka-Kobayashi M, Sawada K, Sculean A, Schaller B, et al. Comparative release of growth factors from PRP, PRF, and advanced-PRF. Clin Oral Investig. 2016;20(9):2353-60. https://doi.org/10.1007/ s00784-016-1719-1

PMid:26809431

37. Needleman IG, Worthington HV, Giedrys-Leeper E, Tucker RJ. Guided tissue regeneration for periodontal infra-bony defects. Cochrane Database Syst Rev. 2006;2:CD001724. https://doi. org/10.1002/14651858.cd001724

PMid:16625546

38. Sebben AD, Hoff G, Klein CP, Freitas TA, Assad C, Santos LA et al. Comparative study on use of platelet-rich plasma alone and in combination with alpha-tricalcium phosphate cement for bone repair in rats. Rev Bras Ortop. 2015;47(4):505-12. https:// doi.org/10.1016/s2255-4971(15)30137-3 PMid:27047859

39. Ozdemir B, Okte E. Treatment of intrabony defects with betatricalciumphosphate alone and in combination with platelet-rich plasma. J Biomed Mater Res B Appl Biomater. 2012;100(4):97683. https://doi.org/10.1002/jbm.b.32660 PMid:22287494

40. Gojkov-Vukelic M, Hadzic S, Gojkov E. Evaluation of efficacy of surgical periodontal therapy with the use of bone graft in the treatment of periodontal intrabony defects. Med Arch. 2017;71(3):208-11. https://doi.org/10.5455/ medarh.2017.71.208-211

PMid:28974835

41. Gokhale ST, Dwarakanath $H$. The use of a natural osteoconductive porous bone mineral (Bio Oss ${ }^{\mathrm{TM}}$ ) in infrabony periodontal defects. J Indian Soc Periodontol. 2012;16:247-52. https://doi.org/10.4103/0972-124x.99270 PMid:23055593

42. Chhina S. A 12 months clinical and radiographic study to assess the efficacy of open flap debridement and subepithelial connective tissue graft in management of supracrestal defects. J Int Oral Health. 2015;7(8):108-13. 
PMid:26464551

43. Trombelli L. Which reconstructive procedures are effective for treating the periodontal intraosseous defect? Periodontol 2000. 2005;37:88-105. https://doi. org/10.1111/j.1600-0757.2004.03798.x

PMid:15655027

44. Patel S, Dhillon MS, Agarwal S, Marwaha N, Jain A. Treatent with platelet rich plasma is more effective than placebo for knee osteoarthritis: A prospective, double-blind, randomized trial. Am J Sports Med. 2013;41:356-64. https://doi. org/10.1177/0363546512471299

45. Marx Re, Carlson RE, Eichstaedt RM, Schimmele SR, Strauss JE, Georgeff KR. Platelet-rich plasma: Growth factor enhancement for bone grafts. Oral Surg Oral Med Oral Pathol Oral Radiol Endod. 1998;85(6):638-46. https://doi.org/10.1016/ s1079-2104(98)90029-4

PMid:9638695

46. Kobayashi E, Fluckiger L, Fujioka-Kobayashi M, Sawada K, SculeanA, Schaller B, et al. Comparative release of growth factors from PRP, PRF, and advanced-PRF. Clin Oral Investig. 2016;20(9):2353-60. https://doi.org/10.1007/ s00784-016-1719-1

PMid:26809431

47. Albanese A, Licata ME, Polizzi B, Campisi G. Platelet-rich plasma (PRP) in dental and oral surgery: From the wound healing to BNE regeneration. Immun Ageing. 2013;10:23. https://doi.org/10.1186/1742-4933-10-23

48. Dohan DM, Choukroun J, Diss A, Dohan SL, Dohan AJ, Mouhyi J, et al. Platelet-rich fibrin (PRF): A second-generation platelet concentrate. Part II: Platelet-related biologic features. Oral Surg Oral Med Oral Pathol Oral Radiol Endod. 2006;101:e45-50. https://doi.org/10.1016/j.tripleo.2005.07.009

49. Ehrenfest DM, Bielecki T, Mishra A, Borzini P, Inchingolo F,
Sammartino $G$, et al. In search of a consensus terminology in the field of platelet concentrates for surgical use: Platelet-rich plasma (PRP), platelet-rich fibrin (PRF), fibrin gel polymerization and leukocytes. Curr Pharm Biotechnol. 2012;13(7):1131-7. https://doi.org/10.2174/138920112800624328

PMid:21740379

50. Kawazoe T, Kim HH. Tissue augmentation by white blood cellcontaining platelet-rich plasma. Cell Transplant. 2012;21(2-3): 601-7. https://doi.org/10.3727/096368911×605538

PMid:22793069

51. Perut F, Filardo G, Mariani E, Cenacchi A, Pratelli L, Devescovi V, et al. Preparation method and growth factor content of platelet concentrate influence the osteogenic differentiation of bone marrow stromal cells. Cytotherapy. 2013;15(7):830-9. https:// doi.org/10.1016/j.jcyt.2013.01.220 PMid:23731763

52. Pirraco RP, Reis RL, Marques AP. Effect of monocytes/ macrophages on the early osteogenic differentiation of hBMSCs. J Tissue Eng Regen Med. 2013;7(5):392-400. https:// doi.org/10.1002/term.535 PMid:22392849

53. Zumstein MA, Berger S, Schober M, Boileau P, Nyffeler RW, Horn $\mathrm{M}$, et al. Leukocyte- and platelet-rich fibrin (L-PRF) for long-term delivery of growth factor in rotator cuff repair: Review, preliminary results and future directions. Curr Pharm Biotechnol. 2012;13:1196-206. https://doi. org/10.2174/138920112800624337

PMid:21740372

54. Dvorak HF, Harvey VS, Estrella P, Brown LF, McDonagh J, Dvorak AM. Fibrin containing gels induce angiogenesis. Implications for tumor stroma generation and wound healing. Lab Invest. 1987;57:673-86.

PMid:2447383 